\title{
Malakoplakia of Head and Neck Mimicking Malignant Lymphadenopathy: A Case Report
}

\author{
Jun Young An, Ho-Ryun Won, Dong Young Kim, and Yoo Seob Shin (D) \\ Department of Otolaryngology, School of Medicine, Ajou University, Suwon, Korea
}

악성 경부임파선병증으로 오인된 연판화증 1예

안준영 · 원호륜 · 김동영 · 신유섭

아주대학교 의과대학 이비인후과학교실

\author{
Received January 18, 2018 \\ Revised March 5, 2018 \\ Accepted March 9, 2018 \\ Address for correspondence \\ Yoo Seob Shin, MD, PhD \\ Department of Otolaryngology, \\ School of Medicine, Ajou University, \\ 206 World cup-ro, Yeongtong-gu, \\ Suwon 16499, Korea \\ Tel +82-31-219-5262 \\ Fax +82-31-219-5264 \\ E-mail ysshinmd@ajou.ac.kr
}

\begin{abstract}
Malakoplakia is usually found in the genitourinary tract; however, it occurs uncommonly as a chronic inflammatory disease and rarely in the head and neck area, having been reported in the literature only few times. Here, we report, with a review of the related literature, a case of malakoplakia on the posterior neck. A 76-year-old male patient visited our institution presenting a rapidly growing neck mass that had invaded the overlying skin for several weeks. The results of imaging studies strongly indicated a malignant tumor, but an accurate diagnosis was not made until after a fine needle aspiration biopsy was undertaken twice. The lesion was completely excised with an extended radical neck dissection including the overlying skin and scalene muscle upon consent of the patient. The pathological diagnosis was made with various immunohistochemical staining methods including Von Kossa, Periodic acid-Schiff-diastase, CD-68 and CD163. During the 24 months follow-up after the surgery, there was no sign of recurrence.

Korean J Otorhinolaryngol-Head Neck Surg 2019;62(4):246-9
\end{abstract}

\section{서 론}

연판화증(malakoplakia)은 1902년 Michaelis와 Gutmann ${ }^{1)}$ 에 의해 처음 기술된 만성 육아종성 염증 질환으로, 주로 비 뇨기계에서 호발하나, 전신의 거의 모든 장기에서 발생할 수 있다. 경부를 침범하는 연판화증은 매우 드물어서 현재까지 의 문헌 보고는 전 세계적으로 약 10 예에 불과하며, ${ }^{2}$ 국내에 서는 아직까지 보고된 바가 없다. 저자들은 악성 종양으로 오 인되었던 경부 연판화증 1 예를 경험하였고, 이 병변에 대한 임상 양상 및 경과를 문헌고찰과 함께 보고하고자 한다.

This is an Open Access article distributed under the terms of the Creative Common Attribution Non-Commercial License (http://creativecommons.org/licenses/by-nc/4.0) which permits unrestricted non-commercial use, distribution, and reproduction in any medium, provided the original work is properly cited.
증 례

76세 남자 환자가 내원 2달 전 시작하여 점차 진행되는 좌 측 경부 종물 및 통증을 주소로 내원하였다. 환자는 당뇨 등 특이 내과적 질환이나 약물복용력은 없었으나, 내원 40년 전 후복막강 내 지방육종을 진단받고 절제 수술을 시행 받았으 며, 5년 전 담낭제거수술(담낭결석) 및 3년 전 좌측 갑상선 절제술(림프구성 갑상선염)을 시행 받은 과거력이 있었다. 내 원 1달 전 타 병원에서 전산화단층촬영 및 조직검사를 시행 하였으며, 영상학적으로는 악성종양 소견을 보였으나, 2차례 시행한 초음파 유도 하 조직 검사상 다량의 포말세포와 함께 만성 염증 소견을 보였다. 이에 정확한 진단 및 치료를 위해 본원으로 전원 되었다. 좌측 경부 촉진 시, 단단하고 압통을 동반하는 $5 \mathrm{~cm}$ 크기의 종괴가 확인되었다. 혈액 검사에서 혈 색소 $11.8 \mathrm{~g} / \mathrm{dL}$, 백혈구 수 $6.7 \times 10^{3} / \mu \mathrm{L}$, 혈소판 수 $204 \times 10^{3} /$ 
$\mu \mathrm{L}, \mathrm{C}$-reactive protein 0.15로 정상이었다. 타 병원에서 시행 된 경부임파선 세균배양 검사상 Escherichia coli(E. coli)가 배양되었다. 경부 전산화단층촬영에서 좌측 II, III 구역에서 불규칙한 조영 증강 및 주변 조직으로의 침윤을 보이는 5 $\mathrm{cm}$ 의 거대한 종괴가 보였다(Fig. 1A). 경부 자기공명영상 촬 영에서 흥쇄유돌근 및 내경정맥과 진피 침범소견을 보였다 (Fig. 1B). 과거력상 지방육종을 치료받은 과거력 및 영상의
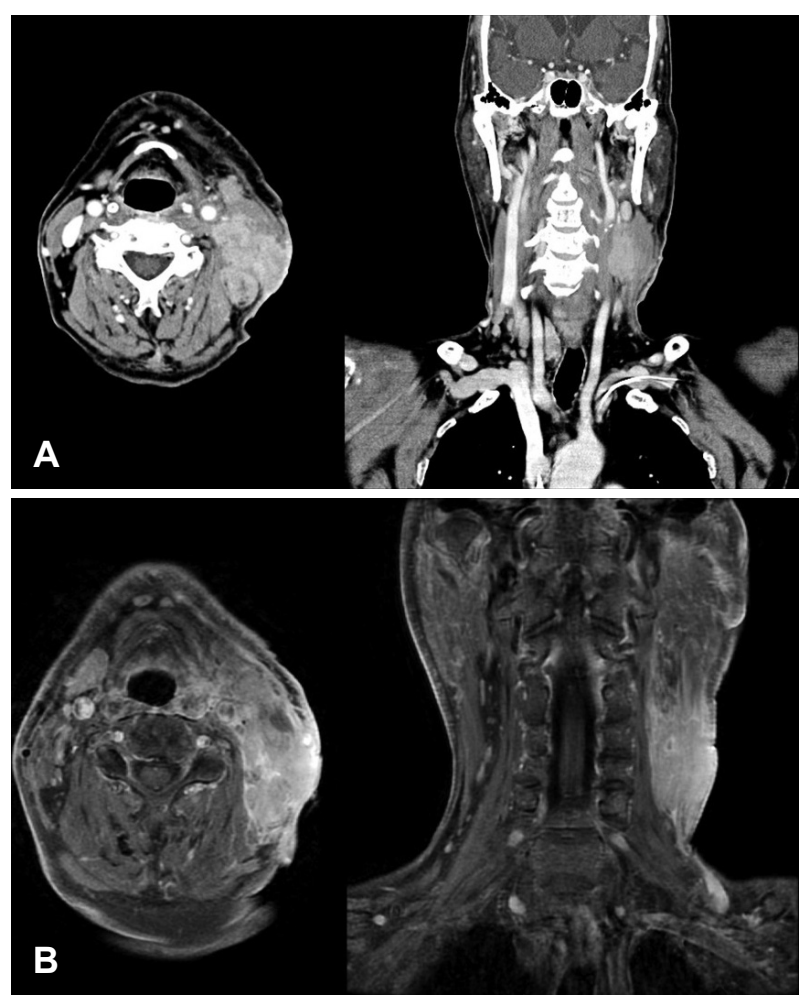

Fig. 1. Preoperative radiologic findings of the patient. Contrast enhanced CT scan shows the heterogeneously enhanced lesion with central necrosis at left level II, III (A). Contrast enhanced MRI shows conglomerated pathologically enlarged lymph nodes at left level II, III with overlying skin, internal jugular vein and sternocleidomastoid muscle invasion (B).
학적 검사상 악성종양이 의심되는 점, 2 차례 세침흡인검사에 서 정확한 진단을 얻지 못한 점을 고려하여 악성종양에 준하 여 근치적 경부임파선 절제술을 계획하였고, 환자에게는 이 에 대해 설명하고, 최종적인 조직진단에 따라 치료방침을 결 정하는 것으로 동의를 구한 후 수술을 진행하였다.

수술은 전신마취 하 앙와위 상태에서 경부와 두부를 신전 시킨 상태에서 시행되었다. 피부를 포함하여 Hockey stick 절개를 가한 후(Fig. 2A), 광경근하 피판을 거상하여 수술 부 위를 충분히 노출하였다. 종물은 바깥쪽으로는 피부 및 흥쇄 유돌근을 침범하고 있었으며 척수부신경(spinal accessory nerve), 내경정맥 및 사각근(scalene muscle)을 침범하고 있 어 이를 포함하여 en bloc으로 절제하였으며, 다행히 횡경막 신경, 상완신경총, 미주신경 및 내경동맥은 손상 없이 보존할 수 있었다(Fig. 2B and C). 절제된 피부는 일차 봉합으로 추 가적인 피판술 없이 봉합할 수 있었다.

병리조직소견에서 다수의 염증성 세포들이 산재되어 있었 는데, 대부분이 호산구성 과립이 풍부한 von Hansemann 세 포였다. 조직구의 세포질 내와 세포 바깥에 석회화된 타겟 모 양의 Michaelis-Gutmann body가 확인되었고, Von-Kossa 염 색에 양성을 보였다(Fig. 3). Hematoxylin \& Eosin 염색소견 과 면역조직화학 염색 소견은 연판화증 진단에 합당하였다.

본원에서 절제된 조직에서 따로 배양 검사가 이루어지지는 않았으나, 연판화증의 경우 E. coli 및 Rhodococcus equi 감 염이 가장 흔하여 두 균주에 모두 배제하기 어려워 감염내과 협진 하에 두 균주 모두 치료가 가능한 azithromycin $250 \mathrm{mg}$, rifampin $600 \mathrm{mg}$ 을 경구 투여 시작하였다. 환자는 수술 후 합병증 없이 퇴원하였으며, 퇴원 후에도 경구 항생제를 10 일 간 복용 후 중단하였으며, 24개월간 재발이 없어 외래추적관 찰을 종료하였다.
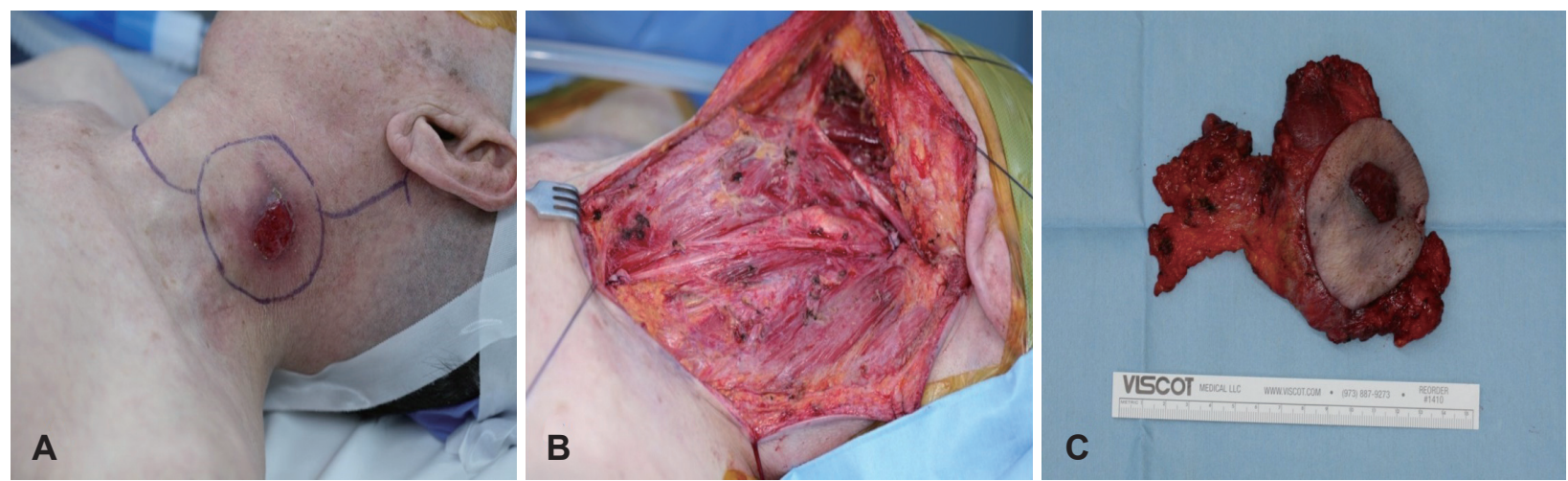

Fig. 2. Surgical findings of the patients. A hockey stick incision including overlying involved skin was designed (A). Extended radical neck dissection including overlying skin was performed. Phrenic nerve, vagus nerve, brachial plexus and carotid artery was preserved (B). The specimen specimen consists of $12 \times 11 \times 3.5 \mathrm{~cm}$ sized well-circumscribed mass with overlying skin (C). 

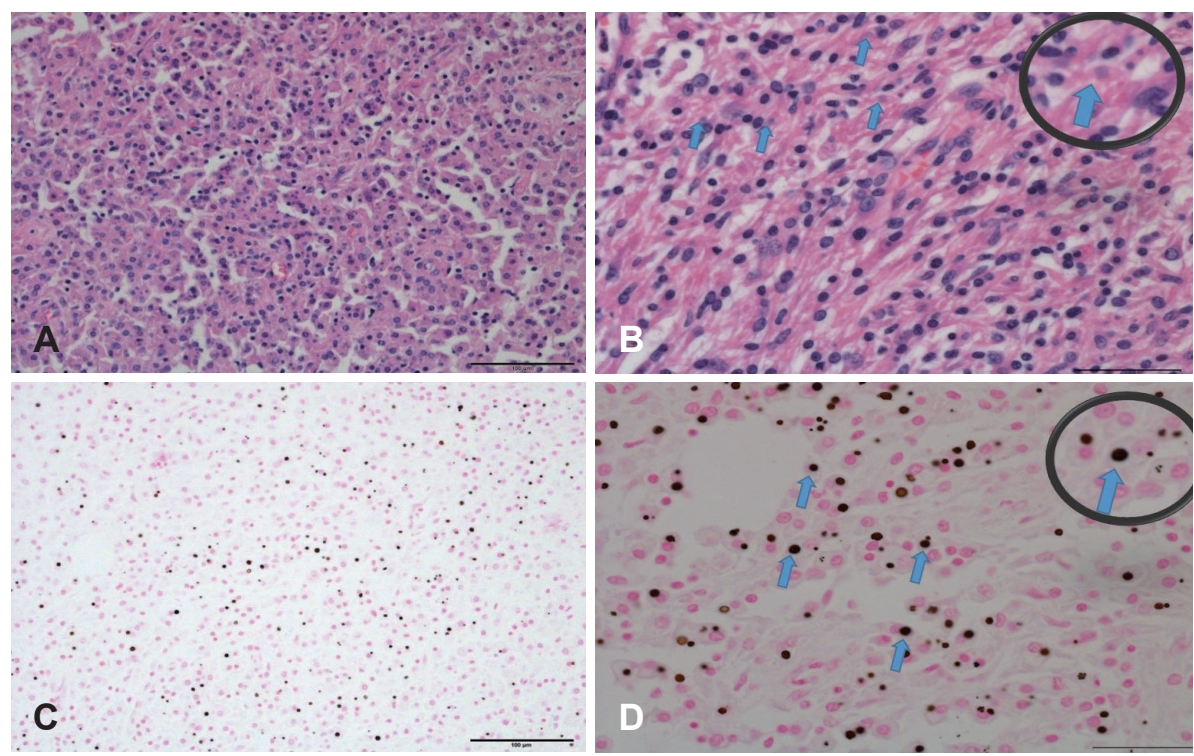

Fig. 3. Histologic finding of the specimen. H\&E staining revealed numerous histiocytes (von Hansemann cells) which have abundant glandular and degenerated cytoplasm (arrows) $(H \& E, A: \times 200, B: \times 400)(A$ and $B$ ). Michaelis-Gutmann bodies stained as black with von Kossa stain (arrows) (Von kossa stain, C: $\times 200$, D: $\times 400)(C$ and D). H\&E: Hematoxylin \& Eosin.

\section{고 찰}

연판화증은 비교적 드문 만성 육아종성 염증 질환으로, 주로 중년 여성의 비뇨기계, 특히 방광에 호발하지만 위장관, 뼈, 뇌, 폐, 피부, 림프절 등 전신의 거의 모든 장기에서 보고 되고 있다. ${ }^{3}$ 발생 연령층도 다양하나 50세 이상에서 호발하는 것으로 알려져 있다. ${ }^{4}$ 이번 증례와 같이 두경부에 발생하는 연판화증은 매우 드물며, 전 세계적으로 약 10 예가 보고되어 있고, ${ }^{5)}$ 국내에서는 현재까지 보고된 바가 없다. 연판화증은 악성 종양으로 쉽게 오인될 수 있으나, 악성으로의 변화는 보 고된 바 없으며, 적절한 절제술과 내과적 치료로서 대부분 치 료되는 것으로 보고되었다.

그 원인과 병인이 아직 잘 밝혀져 있지는 않고 감염, 면역 질환, 전신질환, 악성종양 그리고 유전적인 질환 등 다양한 원인에 의해 발생할 수 있는 것으로 생각되며, 특히 세균 감염 과 상관관계가 있는 것으로 여겨지는데, 93 명의 연판화증 환 자를 분석한 한 연구에서 $89 \%$ 가 coliform bacteria에 감염 된 것이 확인되었으며 coliform bacteria 중에서는 E. coli가 $72 \%$ 로 가장 많았고 그밖에 Rhodococcus, Lebsiella, Enterobacter, Proteus, Pseudomonas species 등이 있었다. ${ }^{6}$ 면역 기능 장애 역시 연관이 있는 것으로 알려져 있어 악성 종양, 면역결핍질환, 자가면역질환 등의 질환이나 신장 이식 환자, 스 테로이드를 장기 복용했던 환자에서 발생하는 경향이 있다. ${ }^{6}$ 연판화증의 발생기전은 대식세포의 기능장애로 인해 발생 하는 것으로 알려져 있는데, cyclic guanosine monophosphate (cGMP) 농도가 감소하여 세포 내 소관의 기능이 저하되고, 이에 따라 대식세포 내 용해 소체의 과립분비가 저하되고 탐 식된 세균이 불완전하게 용해되고, 그 일부가 무기질의 침착
으로 석회화되면서 연판화증이 발생하게 되는 것으로 추정 된다. ${ }^{7)}$

진단은 쉽지 않으며 악성 종양으로 오진되는 경우도 드물지 않다. 감별 진단을 위해 혈액검사 및 영상검사를 시행하지만 최종적인 확진을 위해서는 조직검사가 필요하다. Von Hansemann 세포로 불리는 호산성 과립을 다량 함유하고 있는 세포질이 풍부한 대식세포 및 세포질 내와 세포 바깥에 칼슘 과 철, 인이 침착된 구형의 Michaelis-Gutmann 소체가 확인 되는 경우 연판화증으로 진단할 수 있다. Michaelis-Gutmann 소체는 Periodic acid-Schiff-diastase 염색 또는 Von Koss 염 색에 양성 반응을 보인다.2)

경부 연판화증의 치료로는 아직 정립된 치료 방법이 없는 상태이나 수술적 절제와 항생제 치료를 조합하는 방법이 이용 되고 있다. ${ }^{2}$ 수술적 절제는 괴사조직만을 절제하는 것에 비해 병변 전체를 절제하는 것이 더 효과적이며, 항생제 선택은 세 포 내부(대식세포 내부)로의 침투가 우수한 fluoroquinolone 등의 항생제를 이용한 치료가 많이 시행되고 있다. 본 증례 에서는 외부병원에서 시행한 배양 검사상 E. coli가 배양되었 으며, azithromycin과 rifampin에 감수성을 보여 상기 항생제 를 먼저 사용하였다. 두경부 영역 중 larynx, frontal \& ethmoid sinus 등을 제외하고, 특히 경부종물으로 진단된 연판화증의 경우 4예가 보고되었으며 모두 광범위절제술과 항생제 치료 로 치료되었다. Bethanecol과 같은 콜린성 약물을 투여할 수 도 있는데, 이는 대식세포 내의 cGMP 농도를 높여 대식세포 의 기능 활성화에 도움이 될 수 있다. ${ }^{8)}$

본 환자에서는 오랜 기간 항생제 사용을 하였음에도 불구 하고 경부 종물의 크기가 점점 증가하였고, 동통 외 다른 증 상이 없었으며, 영상학적으로 악성 종양이 강하게 의심되어 
수술적 치료를 하였으며, 최종적인 병리소견에서 연판화증으 로 확인되었다. 연판화증은 그 임상 양상이나 영상학적으로 도 악성 종양과 감별하기 어려우며, 아직 국내에서는 보고된 적이 없는 다소 생소한 질환으로, 동통을 동반한 경부 종물 에 있어서 감염, 악성 종양과 함께 진단이 어려운 경우 감별 진 단의 하나로 고려할 수 있을 것으로 생각한다.

\section{ORCID}

Yoo Seob Shin https://orcid.org/0000-0002-2007-1100

\section{REFERENCES}

1) Michaelis L, Gutmann C. Uber einschlüsse in blasentumoren. $Z$ Klin Med 1902;47:208-15.

2) Garg M, Eley KA, Bond SE, Shah KA, Browning L, Watt-Smith SR. Malakoplakia presenting as an enlarging neck mass: case presentation and review of the literature. Head Neck 2010;32(9): 1269-72.

3) Schmerber S, Lantuejoul S, Lavieille JP, Reyt E. Malakoplakia of the neck. Arch Otolarngol Head Neck Surg 2003;129(11):1240-2.

4) Kumar V, Coady MS. Malakoplakia of the neck in an immunosuppressed patient. Plast Reconstr Surg 2005;116(6):125-7.

5) Coates M, Del Pero MM, Nassif R. A case of cutaneous malakoplakia in the head and neck region and review of the literature. Head Neck Pathol 2016;10(4):444-50.

6) Stanton MJ, Maxted W. Malacoplakia: a study of the literature and current concepts of pathogenesis, diagnosis and treatment. J Urol 1981;125(2):139-46.

7) Oliver JM. Impaired microtubule function correctable by cyclic GMP and cholinergic agonists in the Chediak-Higashi syndrome. Am J Pathol 1976;85(2):395-418.

8) Abdou NI, NaPombejara C, Sagawa A, Ragland C, Stechschulte DJ, Nilsson U, et al. Malakoplakia: evidence for monocyte lysosomal abnormality correctable by cholinergic agonist in vitro and in vivo. N Engl J Med 1977;297(26):1413-9. 